\title{
The Changes of House's Spatial Caused by The User's Religiosity in Pondok Indah Housing Estate Semarang
}

\author{
Annisa D. Zalva*, Sumayya A. Fikri, Atiek Suprapti \\ Department of Architecture, Engineering Faculty of Engineering, Universitas Diponegoro, Indonesia \\ *Corresponding e-mail: dzannisa@gmail.com
}

Article info:

Received: 11-12-2018, Revised: 25-12-2018, Accepted: 11-01-2019

\begin{abstract}
Residential houses in Indonesia that now being developed mostly located in a housing estates are designed in the similar form. Many residents conduct to change the house's shape and spatial due to the spaces need to accommodate their daily activity. One of those needs is regarding religiosity to obey the teachings of religion. The religiosity discussed in this research focuses on Islam that refers to the values of Muslim society based on the conception of Hablum-Minallah, hablumminannas, hablum-minal'Alamien which means an Islamic harmony of relations between human and Allah, with others, and with their natural environments. The location of research is in Pondok Indah Housing Estate Semarang that has established for a long time and has undergone many changes of houses. This research intended to see how spatial changes occurs in Pondok Indah and how religiosity plays a role in. The retrieval of research data is done by interview and observation methods. In the changes in the spatial of houses in Pondok Indah Semarang there are influences of religiosity on several aspects, including zoning, space, circulation, and spatial organization. These changes have caused the houses accordance to the concepts of Islamic houses. The concept of Hablum-Minallah's practice influences changes in orientation aspects, Hablum-Minannas influences changes in the house's spatial, zoning, and circulation, and Hablum-Minal'Alamin does not affect any changes.
\end{abstract}

Keywords: House Spatial, Islam, Layout, Religiosity

\section{Introduction}

Indonesia has the biggest Muslim population in the world. As a religion followed by mostly Indonesian population, Islam teaching regulates whole of Muslim life even in the daily life. In this context, Islam also regulates several things about housing. House in Islam are supposed to be a private and conducive place to practice piety to Allah (practice monotheism, praying morality, syari'ah and muamalah). The practice of these activities is summarized in hablum minallah, hablum minannas and hablum minal alamin. (Nurjayanti, et al, 2014)

But in reality, the design of the houses made by most developers have not been considering the religious values of the users proved by no deliberate "specific" space designed for the Prayer Room (Hermawan, 2014). Mostly the designs offered was made only considering the worldly needs of human. While Muslims are required to always carry out their spiritual activities wherever they are, including their house (Akhyar, et al, 2015)

This phenomenon also happened in Pondok Indah Housing in Pedurungan, Semarang. The majority of the people in Pondok Indah Housing are Muslim. The shape of the house that currently occupied also has changed and each citizen often renovates his house. So that it looks different between the shape of the initial house and the shape of the house at this time. Therefore, research needs to be done to find out the reasons for these changes.

The purpose of this research is to find out the changing of spatial layout of a house because of the religiosity and identifying the changes of the house's layout in Pondok Indah Housing. 


\section{Methods}

The study began with the study of the phenomenon of spatial changes that occurred in many housing in Indonesia, then looked for the same phenomenon happened in housing in Semarang and choose Pondok Indah Housing Residence as the object study for this research. The selection of object study was based on the existence of Islamic religious activities organized by the Pondok Indah Housing residents which are quite intensive. The types of activities carried out by residents of Pondok Indah Semarang Housing are:

a. Regular recitation at the mosque every Wednesday

b. Tadarus (the act of reciting Quran together) every Ramadhan month

c. Lecture/Mentoring every Sunday morning

d. Tafsir Qur'an (Quran interpretation) every day after the morning prayer

e. Halaqoh (a religious gathering for the study of Islam) for ladies every week

f. Taman Pendidikan Islam / TPQ (Islamic non-formal education unit for children) every afternoon in the mosque

g. Recitation and other major activities to commemorate Islamic holidays

The research began by arranging license/permission from department and faculty, then to the chief of neighborhood association. And then determining the sample with a simple random sampling method as many as six houses shown in the figure 1

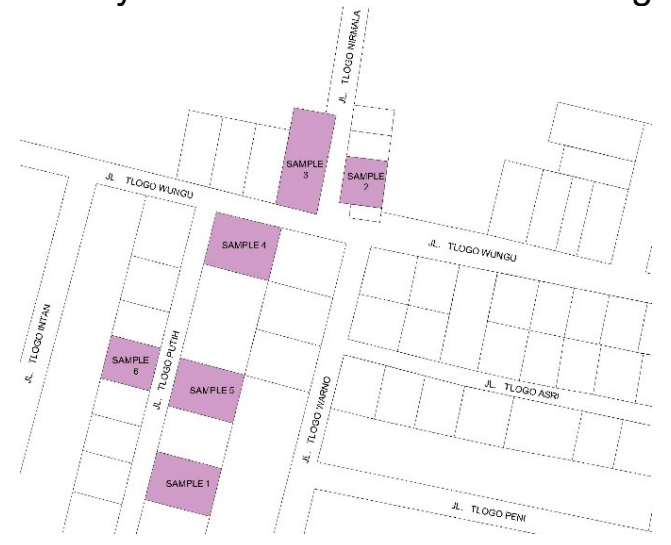

Figure 1. Location of the Research Sample Points (Source: Google Maps, 2018)

The next stage is data retrieval which is divided into primary and secondary data. Primary data is obtained from observations and interviews to the houses owners, while secondary data is obtained through references. Focus of the observation is the current spatial layout of the houses while the aims of the interviews as to find out the changes that occurred and their causes. The tools and materials used include stationery, drawing tools, cell phones, laptops, and meters. The next step is to do the analysis with descriptive method. The last step is to draw the conclusions from the analysis.

\section{Discussion}

Islamic houses are the manifestation of non-physical concepts of Al-Qurans and which is concrete and non-verbal can be expressed to be a physical form of Residence (Nurjayanti \& Ronald, 2011). Some of the non-physical concepts are The Concept of Code to Conduct for Muslim Communities which regulates Muslim's behavior towards God, human, environment and Mahram Non Mahram concepts which regulates about the people we could and shouldn't marry. 


\subsection{The Concept of Code of Conduct for Muslim Communities}

According to Prijontomo and Santosa (1997), Islamic houses are houses based on the values / behavior of Muslim communities. The code of the summarized was conducted in the concept of Hablum Minallah, Hablum Minannas, and Hablum MInal'Alamien. Hablum Minallah is human's behaviour towards God, Hablum Minannas is Muslim's behavior towards others, and Hablum Minal'Alamien is Muslim's behaviour towards the environment. The concept is manifested in the physical form of a muslim residence including its spatial layout. The context are the spatial orientation and the existence of praying space in the house.

According to Mustafa, et al., (2015) the orientation of a good Islamic house is facing the Qibla (the direction that should be faced when a Muslim prays during shalat) so that all spaces are easier to use for praying, better if there is a special prayingroom. The form of the room will be divided into three forms, Rapoport (1980), explains that space is formed because of the fixed element, because of the semi-fixed, and spatial elements with an irregular element (Rifqi, et al., 2014). In addition, we must also pay attention to the orientation of dirty places such as toilets that should not be paralleling the Qibla direction (Budiono \& Anggraeni, 2017).

\subsection{Mahram and Non Mahram concepts}

The concept of Mahram and Non-Mahram is strongly emphasized in the concept of Islamic housing especially in the aspects of zoning and circulation division. QS. An-Nisa: 22-23 explains the difference between Mahram or Non Mahram. Mahram is the opposite sex who is forbidden to be married. And Non Mahram is the opposite sex who can be married. There should be a limit of interaction between the host and non-mahram guests. Therefore, territories that can be accessed by non-Mahram guests is the public zone only (Nurjayanti, et al., 2014). Between the public zone and the other zones there must be a hijab / barrier to protect the privacy of the owner (Rahmah, 2012). The use of curtain to cover the door of house which is became a barrier between the space in the house with the outdoor space (Suprapti, 2014). This concept is used as the consideration for the division of zoning and circulation in the house.

\subsection{The changes of housing spatial in Pondok Indah Residence Semarang}

The following are the results of the data observation in Pondok Indah Residence Semarang

Sample one

The following figure shows the changes of house's spatial in sample one

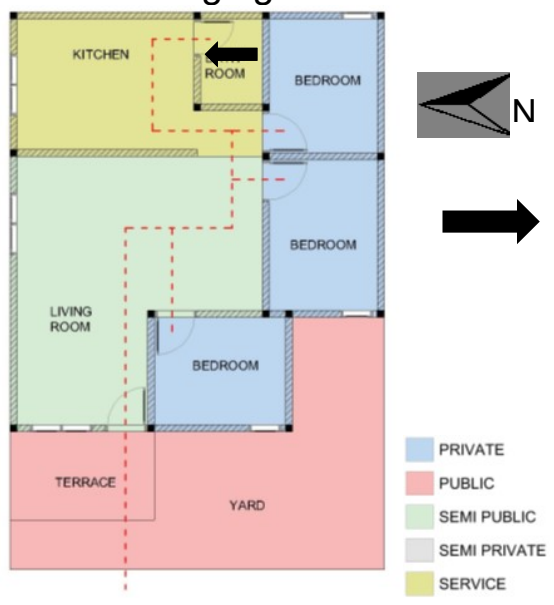

Initial floor plan

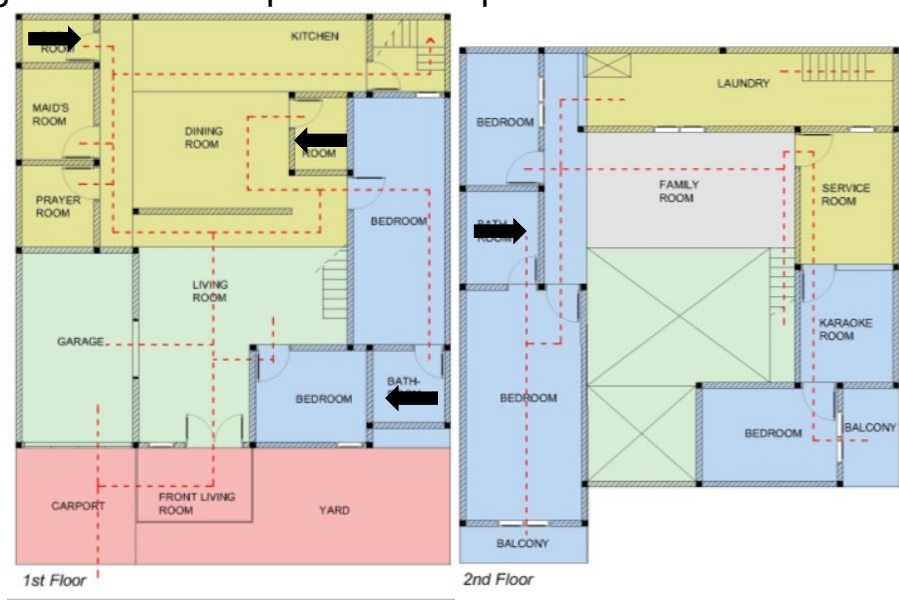

The change of floor plan

Figure 2. Change of Sample one (Source: Interviews and Observations, 2018) 
And the following table explains the changes of house's spatial in sample one

Table 1. Changes of spatial occurred in Sample one (Source: Interviews and Observations, 2018)

\begin{tabular}{|c|c|}
\hline $\begin{array}{l}\text { Aspect of } \\
\text { Changes }\end{array}$ & Changes \\
\hline $\begin{array}{l}\text { Zoning \& Space } \\
\text { Organizations }\end{array}$ & $\begin{array}{l}\text { All private zones are not directly connected to the public } \\
\text { zone } \\
\text { Service zones are placed the farthest from the public zones } \\
\text { because according to the owner, spaces often used by women } \\
\text { should be separated from public area. } \\
\text { Between zones are mostly separated by walls made of } \\
\text { bricks }\end{array}$ \\
\hline Circulation & $\begin{array}{l}\text { The addition of entrance through the garage, and also } \\
\text { additional circulation to the second floor through the living room } \\
\text { stairs and stairs in the service area. } \\
\text { The stairs in the service room can only be accessed by } \\
\text { family members, so that the activities of the women family members } \\
\text { in service and private areas are not seen directly by guests. }\end{array}$ \\
\hline $\begin{array}{c}\text { Space } \\
\text { Orientation }\end{array}$ & $\begin{array}{l}\text { Orientation of the house remains facing qibla } \\
\text { All orientation of three additional bathroom are not qibla. }\end{array}$ \\
\hline $\begin{array}{l}\text { Space for } \\
\text { praying }\end{array}$ & $\begin{array}{l}\text { The addition of prayingrooms is the mushola and family } \\
\text { room on the second floor which can be used for halaqoh or } \\
\text { recitations. } \\
\text { The mushola is in the form of a fixed space bounded by } \\
\text { walls. } \\
\text { The family room's furniture can be removed when there is a } \\
\text { halaqoh. So that the praying space is in the form of non-fixed } \\
\text { space, named when there are activities in it. }\end{array}$ \\
\hline
\end{tabular}

Sample two

The following figure (figure 3) shows the changes of house's spatial in sample two

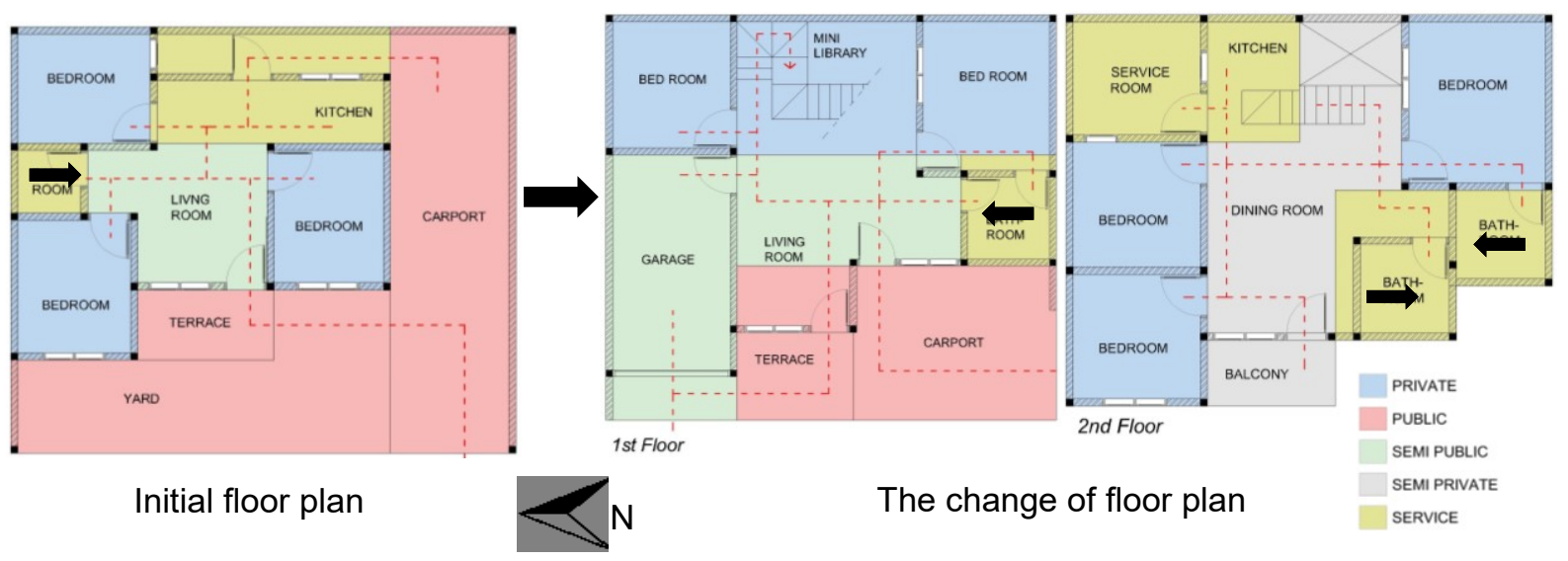

Figure 3. Change of Sample two (Source: Interviews and Observations, 2018)

And the following table explains the changes of House's spatial in sample two 
Table 2. Changes of spatial occurred in Sample two (Source: Interviews and Observations, 2018)

\begin{tabular}{|c|c|}
\hline $\begin{array}{l}\text { Aspect of } \\
\text { Changes }\end{array}$ & Changes \\
\hline $\begin{array}{l}\text { Zoning \& Space } \\
\text { Organizations }\end{array}$ & $\begin{array}{l}\text { The service zone were moved to the second floor. According } \\
\text { to the owner, the zones often used by women must be kept away } \\
\text { from the public area. } \\
\text { Private zones are also not directly connected to the public } \\
\text { zone with a brick wall barrier, this is intended to increase the privacy }\end{array}$ \\
\hline Circulation & $\begin{array}{l}\text { The additional entrance from the garage and also the side } \\
\text { door of the carport. } \\
\text { The addition of circulation to the second floor, where the } \\
\text { owner wants the second floor to be used for activities of female } \\
\text { family members, so that the circulation to the second floor can only } \\
\text { be accessed by family members and female guests only. }\end{array}$ \\
\hline $\begin{array}{c}\text { Space } \\
\text { Orientation }\end{array}$ & $\begin{array}{l}\text { Orientation of the house remains facing qibla } \\
\text { The additional } 2 \text { bathrooms orientation are not facing the qibla }\end{array}$ \\
\hline $\begin{array}{l}\text { Space for } \\
\text { Praying }\end{array}$ & $\begin{array}{l}\text { The prayingroom used is a living room which is usually used } \\
\text { for jamaah (prayer in congregation) prayers and also a halaqoh or a } \\
\text { small recitation. This room is flexible to be used as a prayer room } \\
\text { and also for other activities. } \\
\text { The praying space on sample two is in a form of non-fixed } \\
\text { space. Name of the room was given when room used. }\end{array}$ \\
\hline
\end{tabular}

Sample three

The following figure (figure 4) shows the changes of house's spatial in sample three

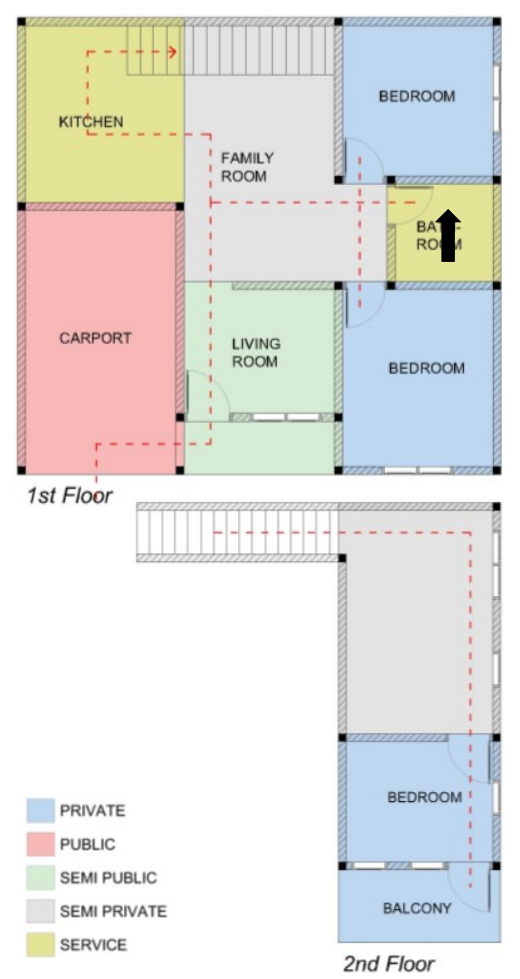

Initial floor plan

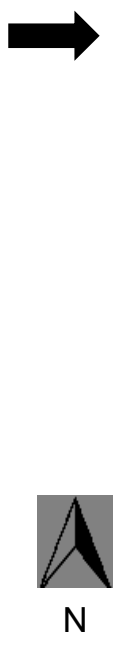

$\mathrm{N}$

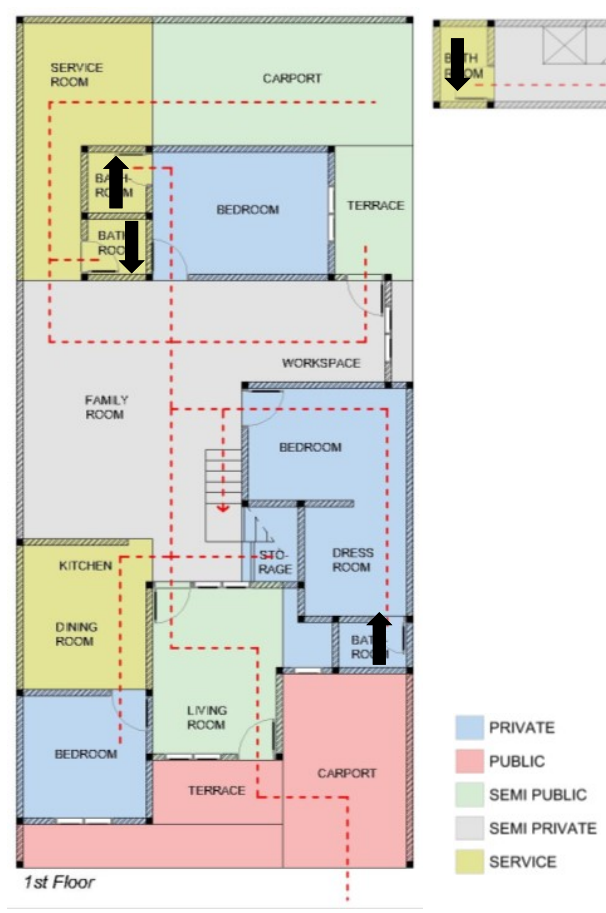

The change of floor plan

Figure 4. Change of Sample three (Source: Interviews and Observations, 2018) 
And the following table explains the changes of House's spatial in sample three

Table 3. Changes of spatial occurred in Sample three (Source: Interviews and Observations, 2018)

\begin{tabular}{cc}
$\begin{array}{c}\text { Aspect of } \\
\text { Changes }\end{array}$ & Changes \\
\hline $\begin{array}{c}\text { Zoning \& Space } \\
\text { Organizations }\end{array}$ & $\begin{array}{c}\text { No consideration about separation of men and women in the } \\
\text { changes that occurred in zoning } \\
\text { There are no considerations regarding the protection of } \\
\text { women in zoning changes }\end{array}$ \\
\hline $\begin{array}{c}\text { There is an additional entrance from the carport at the back } \\
\text { Circulation } \\
\text { of the house. So that family members can enter the house without } \\
\text { being seen by guests from the front door. }\end{array}$ \\
$\begin{array}{c}\text { Space } \\
\text { Orientation } \\
\text { experiencing changes, the orientations are north and east } \\
\text { There is an additional bathroom that is paralleling the qibla }\end{array}$ \\
$\begin{array}{c}\text { There are no special prayer rooms, the family praying in } \\
\text { Space for } \\
\text { Praying }\end{array}$ & $\begin{array}{c}\text { The form of the prayingroom is a non-fixed space that is } \\
\text { their roms. The jamaah prayer is done in the mosque. } \\
\text { named when there are activities in it. }\end{array}$ \\
\hline
\end{tabular}

Sample four

The following figure (figure 5) shows the changes of house's spatial in sample four

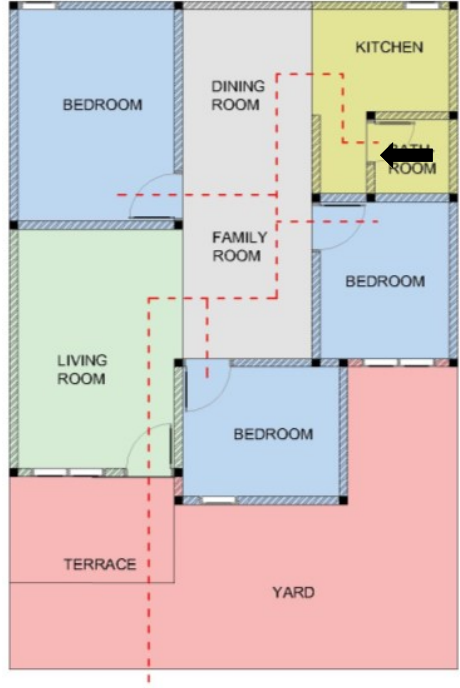

Initial floor plan
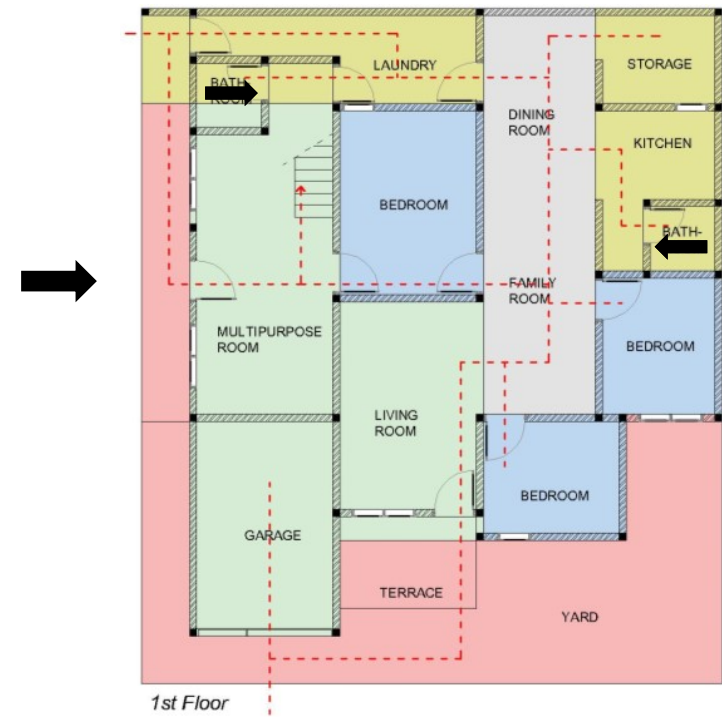

The change of floor plan

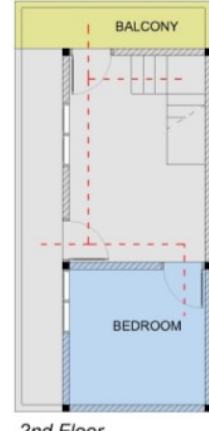

2nd Floor

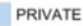

PUBLIC

SEMI PUBLIC

SEMI PRIVATE

SERVICE

Figure 5. Change of Sample four (Source: Interviews and Observations, 2018)

And the following table explains the changes of House's spatial in sample four

Table 4. Changes of spatial occurred in Sample four (Source: Interviews and Observations, 2018)

\begin{tabular}{cc}
\hline $\begin{array}{c}\text { Aspect of } \\
\text { Changes }\end{array}$ & Changes \\
\hline $\begin{array}{c}\text { Zoning \& Space } \\
\text { Organizations }\end{array}$ & Wway from other zones by the owner to protect the privacy of the \\
\hline
\end{tabular}




\begin{tabular}{cl}
\hline Table 4 Continue ... & $\begin{array}{c}\text { The service zone is placed far from the public zone by the } \\
\text { owner with the intention of protecting the privacy of women who } \\
\text { carry out many activities in the service zone }\end{array}$ \\
\hline $\begin{array}{c}\text { The addition of entrance through the back door and the } \\
\text { addition of circulation to the } 2^{\text {nd }} \text { floor. The addition of the back door } \\
\text { is intended for hosts to be able to access the house without being } \\
\text { seen from non Mahram guests. }\end{array}$ \\
\hline $\begin{array}{c}\text { Space } \\
\text { Orientation }\end{array}$ & $\begin{array}{l}\text { Orientation of the house remains facing qibla } \\
\text { All of the additional bathrooms are not paralleling the qibla }\end{array}$ \\
\hline $\begin{array}{c}\text { The prayingroom is in the form multipurpose room that can } \\
\text { Praying }\end{array}$ & $\begin{array}{l}\text { be used for jamaah prayers and halaqoh or small recitations, There } \\
\text { is no fixed furniture in the multipurpose room so it can be used for } \\
\text { praying activities. } \\
\text { The form of the praying space is the non-fixed space. Name }\end{array}$ \\
& \begin{tabular}{l} 
of the room was given when room used. \\
\hline
\end{tabular}
\end{tabular}

Sample five

The following figure (figure 6) shows the changes of house's spatial in sample five

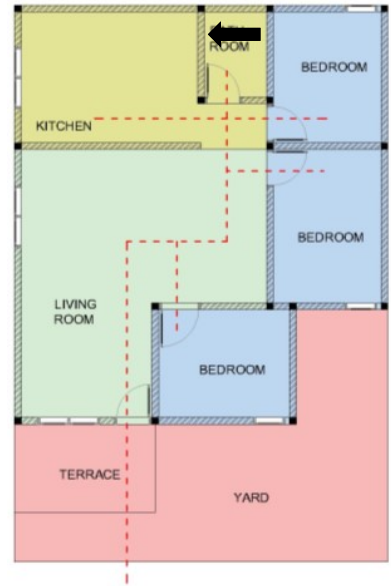

Initial floor plan
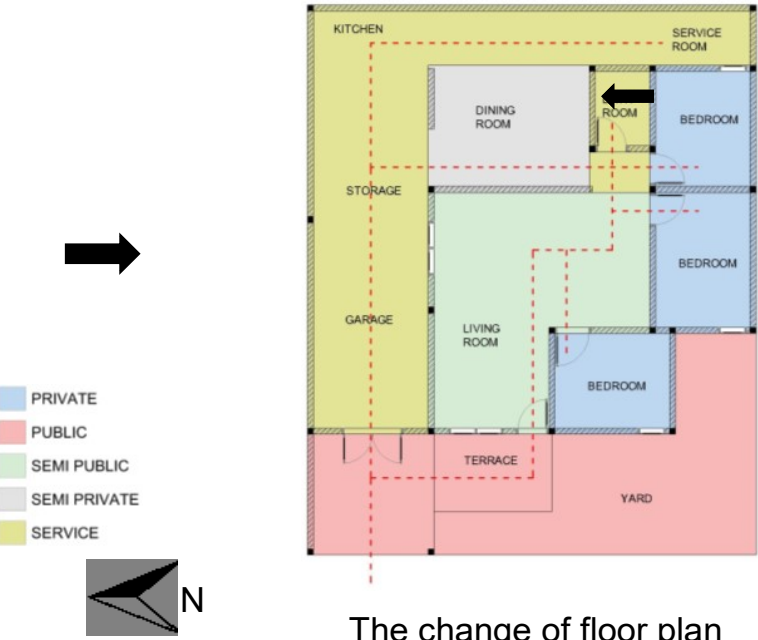

The change of floor plan

Figure 6. Change of Sample five (Source: Interviews and Observations, 2018)

The following table explains the changes of House's spatial in sample five

Table 5. Changes of spatial occurred in Sample five (Source: Interviews and Observations, 2018)

\begin{tabular}{cc}
\hline $\begin{array}{c}\text { Aspect of } \\
\text { Changes }\end{array}$ & \multicolumn{1}{c}{ Changes } \\
\hline $\begin{array}{c}\text { Zoning \& Space } \\
\text { Organizations }\end{array}$ & $\begin{array}{c}\text { The owner placed the service zones accessible from public } \\
\text { zones so they can interact with outsiders at the same time because } \\
\text { the owner often feels lonely by herself. } \\
\text { There is no special zoning for private area according to owner. }\end{array}$ \\
\hline Circulation & $\begin{array}{c}\text { Addition of the entrance through the garage that is directly } \\
\text { connected to the service room. The addition of the entrance is } \\
\text { intended for owner to save the car as well as being used as another } \\
\text { route to enter the house if there are guests. }\end{array}$ \\
\hline Space & Orientation of the house remains facing qibla \\
\hline
\end{tabular}




\begin{tabular}{cc}
\hline \begin{tabular}{c} 
Table 5 Continue ... \\
\hline Orientation
\end{tabular} & $\begin{array}{c}\text { There is no change in the number of bathrooms, and it is } \\
\text { not paralleling the qibla }\end{array}$ \\
\hline $\begin{array}{c}\text { The prayingroom in the form of an unused room that is } \\
\text { converted into a prayer room and living room which is usually used } \\
\text { for halaqoh or recitation. The shape of the prayer room is a fixed } \\
\text { space which is bounded by brick walls. } \\
\text { The form of the praying space is the non-fixed space. Name } \\
\text { of the room was given when the room used. The furniture in the } \\
\text { living room will be removed when used for recitation and carpet is } \\
\text { used as a sitting pad }\end{array}$ \\
\hline
\end{tabular}

Sample six

The following figure shows the changes of house's spatial in sample six

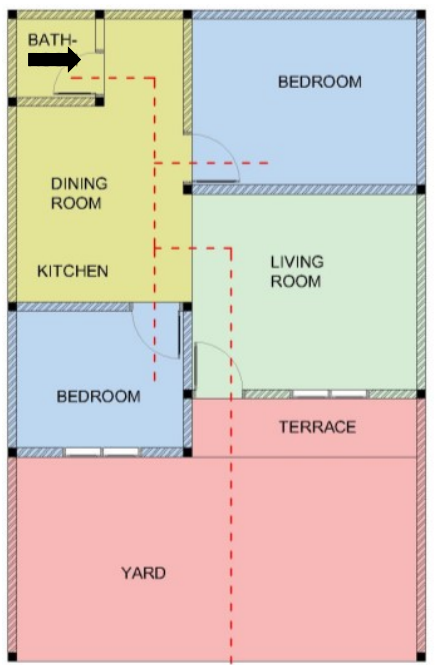

Initial floor plan

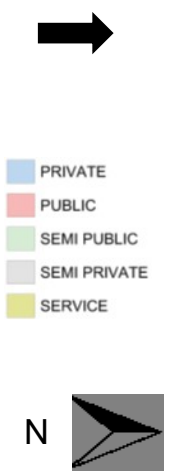

Figure 7. Change of Sample six (Source: Interviews and Observations, 2018)

And the following table explains the changes of House's spatial in sample six

Table 6. Changes of spatial occurred in Sample six (Source: Interviews and Observations, 2018)

\begin{tabular}{cc}
$\begin{array}{c}\text { Aspect of } \\
\text { Changes }\end{array}$ & \multicolumn{1}{c}{ Changes } \\
\hline $\begin{array}{c}\text { Zoning \& Space } \\
\text { Organizations }\end{array}$ & $\begin{array}{c}\text { Placement of a service zone is kept away from the public } \\
\text { zentended by the owner to protect the privacy of his wife, } \\
\text { because this zone is mostly used by his wife } \\
\text { The private zone can't be accessed directly from public } \\
\text { spaces, they are separated by a movable partition. }\end{array}$ \\
Changes in circulation occurred by changing the main \\
Circulation & $\begin{array}{l}\text { Chrculation that was on the right now at the left of the house. } \\
\text { Circulation into the house also has two lanes, through the front door } \\
\text { and side door or from the garage. The side door makes it easier for } \\
\text { host to enter the house when there are guests of the opposite sex. }\end{array}$ \\
\hline $\begin{array}{c}\text { The orientation of the house is paralleling the Qibla but it is } \\
\text { Orientation }\end{array}$ & $\begin{array}{l}\text { Tacing to the east } \\
\text { The orientation of the three additional bathrooms are not } \\
\text { facing the Qibla }\end{array}$ \\
\hline
\end{tabular}


Table 6 Continue ...

There is no special prayer rooms. The family members

Space for praying in their bedrooms. And jamaah prayer is done in the Praying mosque.

The form of the praying space is the non-fixed space that is named when there are activities in it

From the discussion above, there were four aspects that affected the changes of house's spatial. They are zoning, circulation, space orientation, and praying space.

\section{Zoning}

Four out of six houses placed the service zone farthest from the public zone, and even one of them moved it to the $2^{\text {nd }}$ floor with the intention of protecting women who often do activities there, also maintaining the privacy of the family members

The changes occurred are according to the concept of hablum-minannas regarding zoning told in the theory of Nurjayanti et, al., (2014) that territories can be accessed by non-Mahram guests is the public zone only.

\section{Circulation}

All of the six samples add a new circulation which is intended to separate host with non Mahram guests. This is done by adding the entrance to the house (sample Three, four, five, and six), by distinguishing the ladder to access to the second floor (sample one) or selecting guests who can access to the $2^{\text {nd }}$ floor (sample two).

The changes related to the consideration of hablum minannas with the concept of mahram nonMahram in Muslim families are emphasized as the basis for fostering Islamic law, where there are limits to the interaction of hosts and guests, especially between men and women. These are in accordance with the theory of Nurjayanti et, al., (2014) and Rahmah (2012) that territories can be accessed by non-Mahram guests is the public zone only and there must be a barrier between public zone and other zones to protect the privacy of the owner

\section{Space Orientation}

Four of the six houses are oriented to the qibla, one house faces south and another house faces east. No house changed its orientation, they considered the physical characteristics of the Islamic house Hablum-minallah criteria that the House should be parallel to the Qibla direction. This is in accordance with the theory of Mustafa et, al., (2015) that the orientation of a good Islamic house is facing the Qibla so that all spaces are easier to use for praying,

Four of the six houses added bathrooms which its orientation not paralleling the qibla. One house added bathrooms with a bathroom paralleling the qibla. Whereas the-another house does not change the bathroom. This is in accordance with the criteria of the Islamic house regarding the orientation of the bathroom/toilet told in Budiono \& Anggraeni, (2017).

\section{Space for Praying}

There are four houses spatial changes to be able to do jamaah prayer, either by adding a special prayingroom (sample one), or changing the function of a room into a prayingroom (sample two, four, and five). This shows the influence of hablum-minallah according to Mustafa et, al., (2015) that says a good Islamic house is better if it has a special prayingroom The form of the prayingroom in the object studies is divided into two forms, that had explained in Rifqi, et al., (2014) namely the fixed space with wall boundaries (samples one and five), and non-fixed spaces (samples two, three, four, and six) which is named when there are praying activities carried out. 


\section{Conclusion}

Muslim religious activities in Pondok Indah Housing are accommodated in the Mushola and Mosque in the environment scale, and in micro scale are arranged in the houses. To accommodate these activities residents conduct the spatial changes.

The changes of the house's spatial occurred in Pondok Indah Housing has religiosity as one of the consideration, even though it wasn't the main consideration. However, this change intentionally or unintentionally has led to a house that has the concept of Muslim community behavior. Based on the research that has been done, the changes affected by religiosity are:

1. Concept of Hablum Minallah:

There were orientation adjustments of the toilet which is not paralleling the Qibla. And the addition of praying space either by adding a special room or changing the function of a room for praying activities.

2. The concept of hablum minannas:

The concept of hablum-minannas applied in the house's spatial changes is about the limitation of the interactions between hosts and guests indicated by separation of service zones that are commonly used by women and separation of circulation between hosts and non Mahram guests

3. The concept of hablum minal alamin:

No changes affected.

The similar study could be arranged in the different location to know the variation of variables.

\section{References}

Akhyar, Z., Matnuh, H., \& Patimah, S. (2015). Implementasi Toleransi Antar Umat Beragama di Desa Kolam Kanan Kecamatan Barambai Kabupaten Barito Kuala. Jurnal Pendidikan Kewarganegaraan. Vol.5 (No 9).

Budiono \& Anggraeni, L.K. (2017). Desain Toilet dan Tempat Wudhu Masjid. Jurnal Desain Interior, Vol.2 (No.1).

Hermawan, M (2014). Explorasi "Rumah Tinggal Islami" di Kota Pekanbaru. Jurnal Arsitektur Arsitektur Melayu dan Lingkungan, Vol 1 (No 1), 1-10.

Kementrian Agama Republik Indonesia (2014). Al-Qur'an Al-Karim dan Terjemahannya. Surabaya, Indonesia: Halim Publishing \& Distributing.

Mustafa, M., Wikantari, R., Harisah, A., Muftiradja, A. (2015). Kajian Tekstual Nilai-nilai Kelslaman untuk Arsitektur Rumah Tinggal. In Proceedings of the IPLBI Scientific Meeting. Manado, Indonesia: IPLBI (Ikatan Peneliti Lingkungan Binaan Indonesia).

Nurjayanti, W. \& Ronald, A. (2011). Rekayasa Model Disain Rumah Islami Berdasar Studi Eksplorasi Pada Permukiman di Komplek Masjid Menara Kudus. Artikel Publikasi Penelitian Hibah Bersaing.

Nurjayanti, W., Aly, A., \& Ronald,R. (2014). Karakteristik Rumah Tinggal dengan Pendekatan Nilai Islami. In RAPI XIII National Symposium. Surakarta, Indonesia: RAPI (Rekayasa, Aplikasi, Perancangan, dan Industri) XIII.

Prijotomo, J and Santosa, M. (1997). Bunga Rampai Arsitektur ITS. Surabaya: Jurusan Arsitektur Fakultas Teknik Sipil dan Perencanaan Institut Teknologi Sepuluh Nopember

Rahmah, Sukmayati (2012). Pengaruh Hijab Perempuan pada Tata Ruang Rumah Tinggal Muslim. Egalita Jurnal Kesetaraan dan Keadilan Gender, Vol 7 (No 1), 117-131.

Rifqi, M., Antariksa, Suryasari, N. (2014). Posisi Wanita Pada Rumah Tradisional Baanjungan di Banjarmasin. Jurnal Mahasiswa Jurusan Arsitektur Fakultas Teknik, Universitas Brawijaya, Vol 2 (No.1).

Suprapti, A.; Sardjono, B., A, and Harani, R., A. (2014). The Tradition of Living of Muslim Community Kudus Kulon. Journal of Social Sciences Vol 10 (No. 2) 63-73. 